Original Article

\title{
TO ASSESS THE POTENTIAL OF CURCUMIN AGAINST GUT MICROBIOTA-INDUCED ALTERATION IN CHOLINE METABOLISM IN C57BL/6J MICE
}

\author{
HIMANI JOSHI ${ }^{*}$, UMA BHANDARI ${ }^{1}$, BIBHU PRASAD PANDA ${ }^{2}$ \\ ${ }^{1}$ Department of Pharmacology, Faculty of Pharmacy, Jamia Hamdard, New Delhi, ${ }^{2}$ Department of Pharmaceutical Biotechnology, Faculty of \\ Pharmacy, Jamia Hamdard, New Delhi \\ Email: himanij.13@gmail.com
}

Received: 31 Oct 2016 Revised and Accepted: 30 Jan 2017

\section{ABSTRACT}

Objective: The present study was focused on assessing the antimicrobial activity of curcumin against Providencia rettgeri, a gut microbe, which was further corelated to the effect of curcumin on choline metabolism and its role in preventing atherosclerosis and on the evaluation of potential of curcumin on the inhibition of conversion of choline to trimethylamine (TMA), and further its conversion to trimethylamine-N-oxide (TMAO) in liver.

Methods: The minimum inhibitory concentration of curcumin was determined using Cup-plate method. The estimation of trimethylamine was performed using high performance thin layer chromatography (HP-TLC) technique. Estimation of blood serum parameters were performed using kits supplied by Span-diagnostics for estimation of triglycerides, total cholesterol and high density lipoprotein (HDL) cholesterol. All surgical procedures on animals including blood withdrawal and isolation of livers were carried out in accordance with CPCSEA guidelines.

Results: The minimum inhibitory concentration of curcumin was found to be $10 \mu \mathrm{g} / \mathrm{ml}$. There was a significant increase $(\mathrm{p}<0.001)$ in the mean triglyceride, total cholesterol, low-density and very low-density lipoprotein, along with a significant decrease $(\mathrm{p}<0.001)$ in high-density lipoprotein in choline-fed mice. Also, there was significant decrease $(\mathrm{p}<0.001)$ in the mean triglyceride, total cholesterol, low-density and very low-density lipoprotein, along with a significant increase $(\mathrm{p}<0.001)$ in high-density lipoprotein cholesterol in choline-fed mice treated with curcumin. Further, there was a decrease in the Flavin mono-oxygenase $\left(\mathrm{FMO}_{3}\right)$ activity in the mice livers treated with curcumin by $21.57 \%$.

Conclusion: It was concluded that curcumin has the potential to inhibit gut microbiota thus prevention the conversion of choline to trimethylamine, has serum lipid lowering effect in female $\mathrm{C} 57 \mathrm{BL} / 6 \mathrm{~J}$ mice and has an inhibitory effect on hepatic $\mathrm{FMO}_{3}$ thus preventing the conversion of trimethylamine to trimethylamine- $\mathrm{N}$-oxide.

Keywords: Choline, Trimethylamine, Trimethylamine-N-oxide, Curcumin, $\mathrm{FMO}_{3}$, Providencia rettgeri, $\mathrm{C} 57 \mathrm{BL} / 6 \mathrm{~J}$ mice

(C) 2016 The Authors. Published by Innovare Academic Sciences Pvt Ltd. This is an open access article under the CC BY license (http://creativecommons.org/licenses/by/4.0/) DOI: http://dx.doi.org/10.22159/ijpps.2017v9i3.15966

\section{INTRODUCTION}

Trimethylamine-N-oxide (TMAO) was identified to be associated with CVD risks using multinuclear nuclear magnetic resonance (NMR), multi-stage mass spectrometry and gas chromatography (GC) with tandem mass spectrometry (MS/MS) [1]. Trimethylamine (TMA), a metabolite of choline, is further oxidised to TMAO. Also, the catabolism of choline and betaine by the gut microbes results in the formation of TMA gas [2]. This TMA gas, is absorbed the liver and metabolised by hepatic flavin-monooxygenase, $\mathrm{FMO}_{3}$, to form TMAO $[3,4]$. Hepatic $\mathrm{FMO}_{3}$ has been found to be the enzyme for the conversion of TMA to TMAO [4, 5]. Schadt et al., in 2005, identified the possible role of $\mathrm{FMO}_{3}$ in atherosclerosis and found significant correlations between hepatic $\mathrm{FMO}_{3}$ expression and atherosclerotic lesions [6]. Various studies have demonstrated that feeding atherosclerosis-prone mice with diet enriched in either choline or TMAO enhanced atherosclerosis development. Thus, it was established that TMAO accelerates atherosclerosis in genetic knockout mice models $[1,7,8]$.

In 2013, it was demonstrated that the production of TMAO from dietary phosphatidylcholine was dependent on gut microbial metabolism, and the elevated TMAO levels associate with increased risk of incident major adverse cardiovascular events [9]. These studies showed that several phosphatidylcholine metabolites including TMAO were elevated following phosphatidylcholine challenge, as expected in individuals not receiving treatment. In contrast, oral antibiotic treatment abolished TMAO (and TMA) production from dietary phosphatidylcholine, indicating an obligatory role of gut microbes in initiating this pathway in man.

Curcuma longa rhizome has been traditionally used as antimicrobial agent as well as an insect repellant [10]. The pharmacological effects of curcumin are multi-faceted; act as gastro-protectant against irritants in rabbits [11], hepato-protectant activity in dogs [12, 13], increases the activity of pancreatic lipase, amylase, trypsin and chymotrypsin [14], decreases the severity of pathological changes and thus protects from damage caused by myocardial infarction [15], effective against carrageenan-induced edema in rats [16] and mice [17], antioxidant activity [18], induces apoptosis and inhibits cell-cycle progression, both of which are instrumental in preventing cancerous cell growth in rat aortic smooth muscle cells [19].

It is widely appreciated that inflammation and oxidant stress contribute to atherogenesis [20]. In 1992, apoE-deficient mice were generated by inactivating the ApoE gene by targeting [21]. It was hypothesised that curcumin could inhibit the development of atherosclerosis in the apoE/IDLR-double-knockout mice fed with Western diet (21\% fat, $0.15 \%$ cholesterol $\mathrm{w} / \mathrm{w}$, without cholic acid) [22]. Curcumin (purity 98\%), premixed with diet, was given for 4 mo at a dose of $0.3 \mathrm{mg} /$ per day/per mouse. In this model curcumin inhibited atherogenesis, measured both by "en face" method $(25.15 \pm 2.9 \%$ vs. $19.2 \pm 0.6 \%, \mathrm{p}<0.05)$ and "cross-section" method $\left(565867 \pm 39764 \mu \mathrm{m}^{2}\right.$ vs. $\left.299201 \pm 20373 \mu \mathrm{m}^{2}, \mathrm{p}<0.05\right)$. Importantly, curcumin influenced neither the concentrations of cholesterol and triglycerides in blood nor animal body weight. Therefore, in 2005, Olszanecki et al. first reported that shows the anti-atherogenic effect of low dose of curcumin in fine model of atherosclerosis: genetargeted apoE/IDLR-double knockout mice [22]. It was noted that the action of curcumin was present in apoE/IDLR-DKO mice even despite feeding them with Western diet, which greatly accelerates lesion formation, increases lesion size and promotes development of advanced lesions at a significantly earlier age [23, 24]. Taking into granted poor bioavailability of curcumin due to its rapid metabolism in the liver and intestinal wall as well as relatively low dose used 
$(0.3 \mathrm{mg} / \mathrm{mouse} /$ day), the anti-atherogenic action of curcumin was found to be quite strong [22].

The present study was based on evaluation of the potential of curcumin on the inhibition of conversion of choline to TMA, and furthers its conversion to TMAO in liver. The conversion of TMA to TMAO is catalysed by the enzyme $\mathrm{FMO}_{3}$ in liver. Therefore, the $\mathrm{FMO}_{3}$ inhibiting potential of curcumin was assessed in this study. Also, the conversion of choline to TMA by gut microbiota was assessed in the presence and absence of curcumin in order to determine whether curcumin can prevent the production of pro-atherogenic TMAO, and the precursor for its synthesis, i.e., TMA.

\section{MATERIALS AND METHODS}

\section{In vitro analysis of microbial inhibition by the drug}

All the apparatus used was sterilised and all the experiments were performed in aseptic condition. The inoculum containing Providencia rettgeri (MTCC no. 8929) was spread out in agar plate. Five bores of same diameter and depth were made on the agar plate and different dilutions of the test drug $(10,25,50,100 \mu \mathrm{g} / \mathrm{ml})$ were poured on the bores [25]. Ciprofloxacin (procured from International Testing Centre, Chandigarh, India) was used as the standard drug. The minimum concentration at which curcumin (procured from LOBA Chemie Pvt. Ltd., New Delhi, India) showed zone of inhibition was calculated as minimum inhibitory concentration (MIC) value.

\section{In vitro analysis of TMA formed from choline by Providencia} rettgeri in the presence and absence of curcumin

The quantitative estimation of the amount of TMA formed from choline in the sample was determined by HPTLC-UV analysis. The HP-TLC equipment used for analysis was designed by CAMAG and the UV spectrophotometer used was designed by Shimadzu, Japan. For the quantification, a standard plot of serial dilutions of TMA was prepared. $1 \mathrm{ml}$ of $100 \mu \mathrm{g} / \mathrm{ml}$ choline chloride was added to $10 \mathrm{ml}$ nutrient broth containing Providencia rettgeri and was incubated for $30 \mathrm{~min}$ at $37^{\circ} \mathrm{C}$. The incubated samples were mixed with equal volume of chloroform for the extraction of synthesised TMA. The chloroform extract containing TMA were filtered, labelled and stored at $-20^{\circ} \mathrm{C}$ until quantification.

\section{Animals and treatments}

All animal procedures were approved by and carried out in accordance with the Institutional Animal Ethics Committee, Jamia Hamdard (registration no. 173/GO/Re/S/2000/CPCSEA; approval no. 1181). Female C57Bl/6J mice were obtained at the age of $5 \mathrm{w}$ from Central Animal House Facility, Jamia Hamdard (New Delhi, India). Mice were maintained on $12 \mathrm{~h}$ dark/12 h light cycles in airconditioned room $\left(22.5 \pm 0.5{ }^{\circ} \mathrm{C}, 50 \pm 5 \%\right.$ humidity $)$ and access to diet and water ad libitum. Animals were divided into four groups namely, Normal Control (NC, fed with normal pellet diet), Pathogenic Control (PC, fed with $2 \%$ choline diet for $21 \mathrm{~d}$ ), Curcumin-treated (CUR, fed with $2 \%$ choline diet al. ong with curcumin $30 \mathrm{mg}$ P. O. per day for $21 \mathrm{~d}$ ) and Ciprofloxacin-treated (CFX, fed with $2 \%$ choline diet al. ong with ciprofloxacin hydrochloride $100 \mathrm{mg}$ P. 0 . per day for $21 \mathrm{~d}$ ).

\section{Preparation for drug samples for dosing}

Preparation of curcumin suspension: For dosing, curcumin (30 mg P. $0 . /$ mouse o. d.) was suspended in $0.2 \%$ polyethyleneglycol in $0.9 \%$ normal saline ( $0.9 \mathrm{~g}$ sodium chloride in $100 \mathrm{ml}$ of distilled water).
Preparation of ciprofloxacin suspension: For dosing, ciprofloxacin hydrochloride (100 mg P. $0 . /$ mouse o. d.) was suspended in $0.2 \%$ polyethyleneglycol in $0.9 \%$ normal saline.

\section{Biochemical estimation in serum}

After $21 \mathrm{~d}$, blood samples were collected from the retino-orbital site under anaesthesia, and then the mice were sacrificed. Plasma was separated by centrifugation at $2000 \mathrm{rpm}$ at $4{ }^{\circ} \mathrm{C}$ and stored at- $20^{\circ} \mathrm{C}$. The serum was estimated for total cholesterol (TC) [26], triglycerides (TGs) [27], high density lipoprotein (HDL) cholesterol [28], low density lipoprotein (LDL) cholesterol [29], very low density lipoprotein (VLDL) cholesterol [28], and atherogenic risk predictor indices [30]. Estimation of HDL cholesterol, TG and TC were performed using kits supplied by Span Diagnostics Ltd., Surat, India.

\section{Surgical procedures}

Animals were anaesthetized using diethylether during all surgical procedures. Blood samples were withdrawn from retino-orbital plexus. Livers were obtained after euthanization.

\section{Preparation of FMO microsomal homogenate from curcumin treated and untreated mice}

Fresh livers were taken from mice previously treated with cholinefed diet and curcumin for $21 \mathrm{~d}$. Liver from the control group were taken from the mice fed with normal diet for $21 \mathrm{~d}$. Microsomes were isolated from the livers as described by Kamath et al., 1971 [31]. Livers were homogenized in cold homogenization buffer $(0.1 \mathrm{M}$ potassium phosphate, $0.1 \mathrm{mmol}$ dithiothritol, $2 \%$ sucrose, $\mathrm{pH} 9.0$ ) and homogenate was centrifuged at $10,000 \mathrm{xg}$ for $20 \mathrm{~min}$ at $4{ }^{\circ} \mathrm{C}$. The homogenates were stored at $-20^{\circ} \mathrm{C}$.

\section{FMO3 enzyme assay and estimation of TMA converted into TMAO}

The qualitative estimation of the amount of TMA converted into TMAO in the sample was determined by HPTLC-UV analysis. For the quantification, a standard plot of serial dilutions of TMA was used. 1 $\mathrm{ml}$ of $100 \mu \mathrm{g} / \mathrm{ml} \mathrm{TMA}$ was added to $10 \mathrm{ml}$ liver homogenate and was incubated for $30 \mathrm{~min} 37^{\circ} \mathrm{C}$. The incubated samples were mixed with equal volume of chloroform for the extraction of TMA utilised for conversion to TMAO. The chloroform extract containing TMA were filtered with $0.2 \mu \mathrm{m}$ filter. The samples were labelled and stored-20 ${ }^{\circ} \mathrm{C}$ until quantification.

\section{Chromatographic method for estimation of trimethylamine (TMA)}

The mobile phase used during various analysis performed using HPTLC was glacial acetic acid: n-butanol: ethanol: water $(8: 2: 3: 1)$ and the solvent used for dissolution of TMA was ethanol. The detection was performed using ultraviolet spectrometry at wavelengths 254 and $366 \mathrm{~nm}$.

** Statistical analysis was carried out using Graphpad Instat (Graphpad Software: San Diego, CA). All results were expressed as mean \pm SEM Groups of data were compared with an analysis of variance followed by using ANOVA Tukey test.

\section{RESULTS}

\section{In vitro studies}

The minimum inhibitory concentration (MIC) of curcumin was determined to be $10 \mu \mathrm{g} / \mathrm{ml}$ (table 1 ), thus concluding curcumin's anti-bacterial activity against the gut microbe Providencia rettgeri.

Table 1: Zone of inhibition of various concentrations of test and standard drug

\begin{tabular}{llll}
\hline Sample & Concentration $(\boldsymbol{\mu g} / \mathbf{m l})$ & Zone of Inhibition $\boldsymbol{~}^{(\mathbf{m m})}$ & Zone of Inhibition (\%) \\
\hline Ciprofloxacin & 5 & 29.9 & 100 \\
Curcumin & 10 & 16.5 & 55.18 \\
Curcumin & 25 & 12.0 & 40.13 \\
Curcumin & 50 & 13.75 & 45.99 \\
Curcumin & 100 & 12.3 & 41.13 \\
\hline
\end{tabular}

"Values are expressed as mean \pm SEM, $n=3$ 
Table 2: TMA formed from choline in the presence and absence of curcumin and ciprofloxacin by Providencia rettgeri

\begin{tabular}{|c|c|c|}
\hline S. No. & Sample & TMA formed* (ng/ $\mu \mathrm{l})$ \\
\hline 1 & Broth & No detectable TMA \\
\hline 2 & Broth $+P$ rettgeri & No detectable TMA \\
\hline 3 & Broth $+P$ rettgeri + Choline & No detectable TMA \\
\hline 4 & Broth $+P$ rettgeri + Choline $+1 \mu \mathrm{g} / \mathrm{ml}$ Curcumin & No detectable TMA \\
\hline 5 & Broth $+P$ rettgeri + Choline $+5 \mu \mathrm{g} / \mathrm{ml}$ Curcumin & No detectable TMA \\
\hline 6 & Broth $+P$ rettgeri + Choline $+10 \mu \mathrm{g} / \mathrm{ml}$ Curcumin & No detectable TMA \\
\hline 7 & Broth $+P$ rettgeri + Choline $+20 \mu \mathrm{g} / \mathrm{ml}$ Curcumin & No detectable TMA \\
\hline 8 & Broth $+P$ rettgeri + Choline $+1 \mu \mathrm{g} / \mathrm{ml}$ Ciprofloxacin & 2.50 \\
\hline 9 & Broth $+P$ rettgeri + Choline $+5 \mu \mathrm{g} / \mathrm{ml}$ Ciprofloxacin & 17.67 \\
\hline 10 & Broth $+P$ rettgeri + Choline $+10 \mu \mathrm{g} / \mathrm{ml}$ Ciprofloxacin & 28.02 \\
\hline 11 & Broth $+P$ rettgeri + Choline $+20 \mu \mathrm{g} / \mathrm{ml}$ Ciprofloxacin & 2.43 \\
\hline
\end{tabular}

*Values are expressed as mean \pm SEM, $n=5$, TMA-trimethylamine
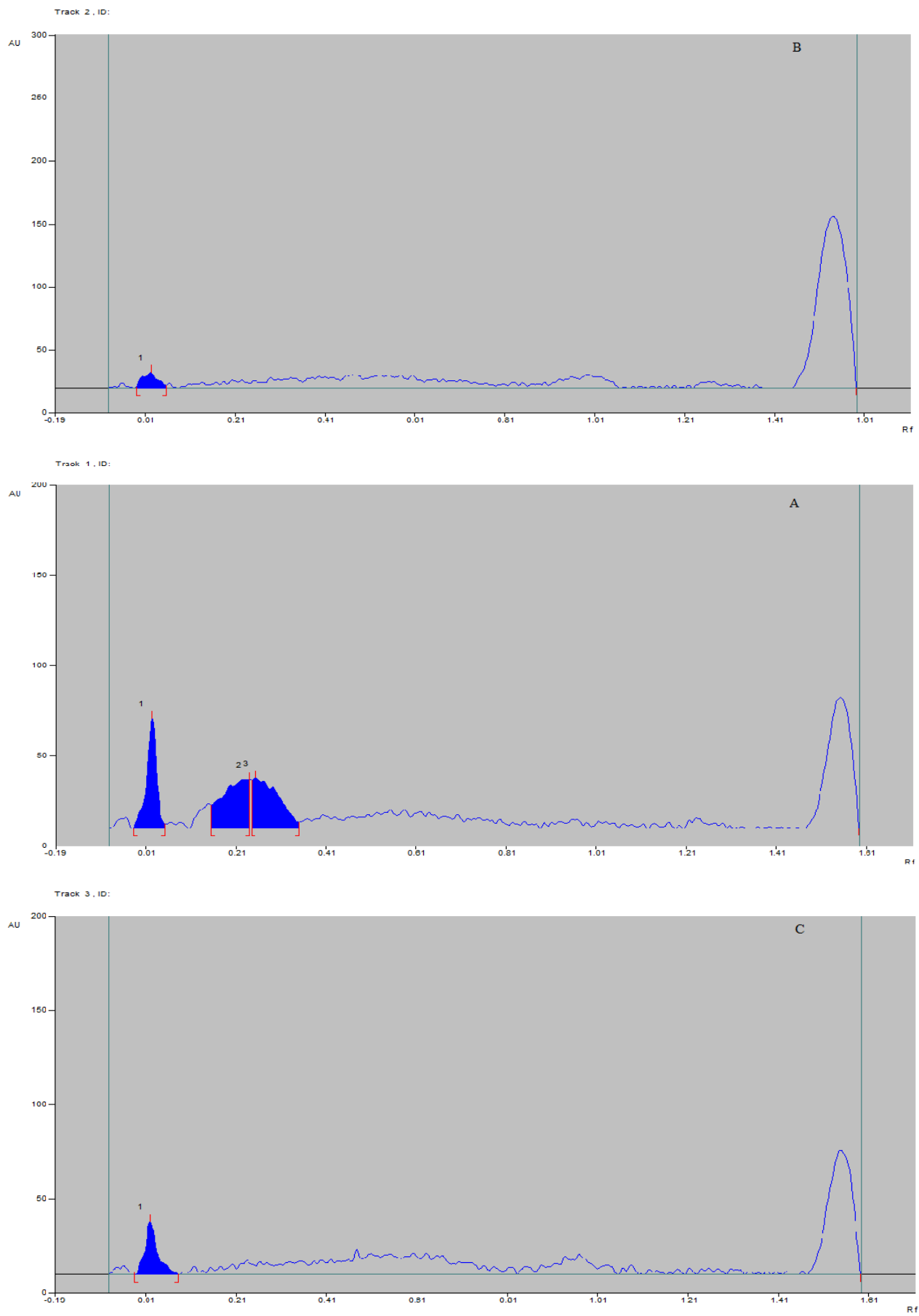

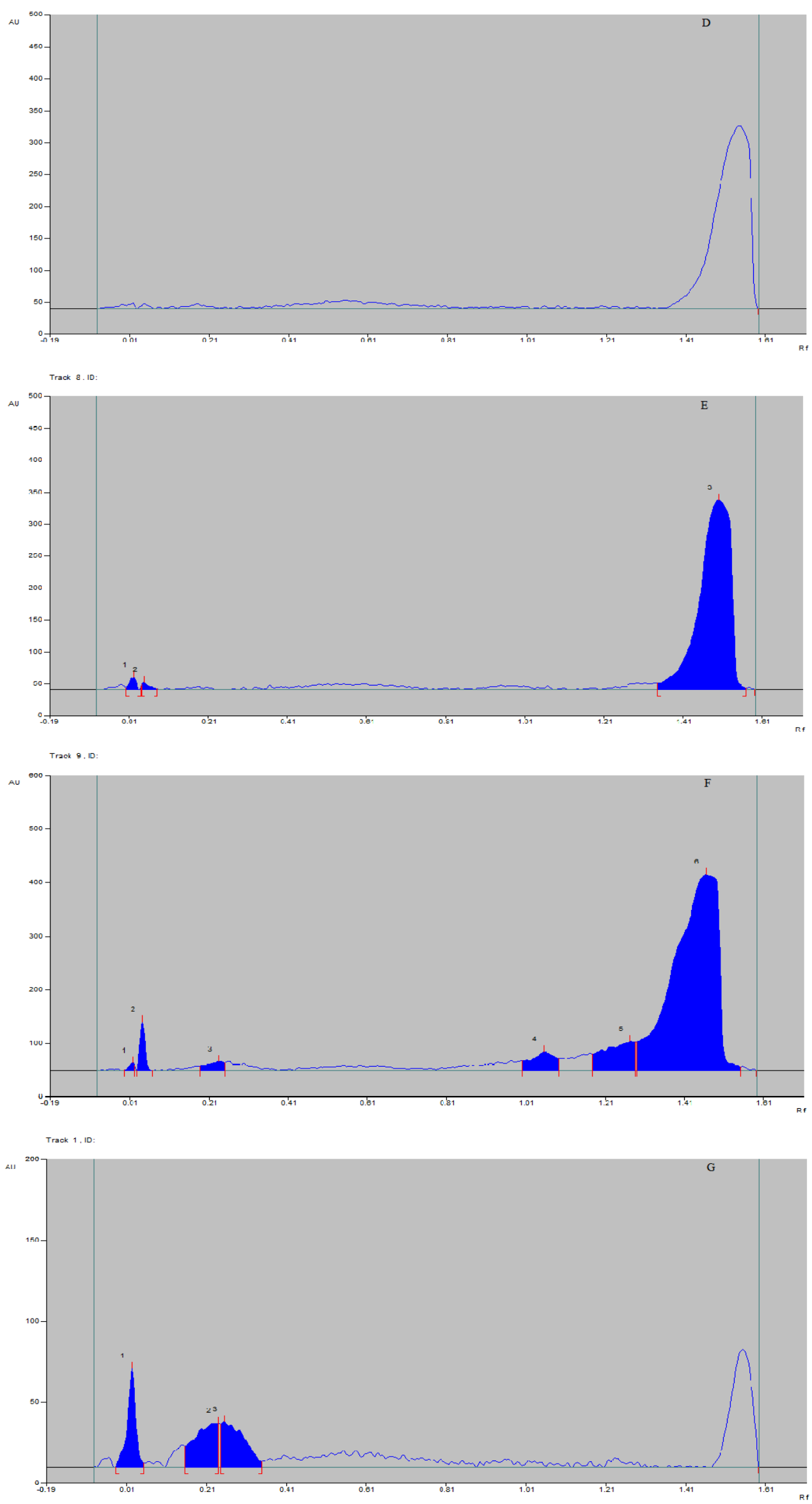

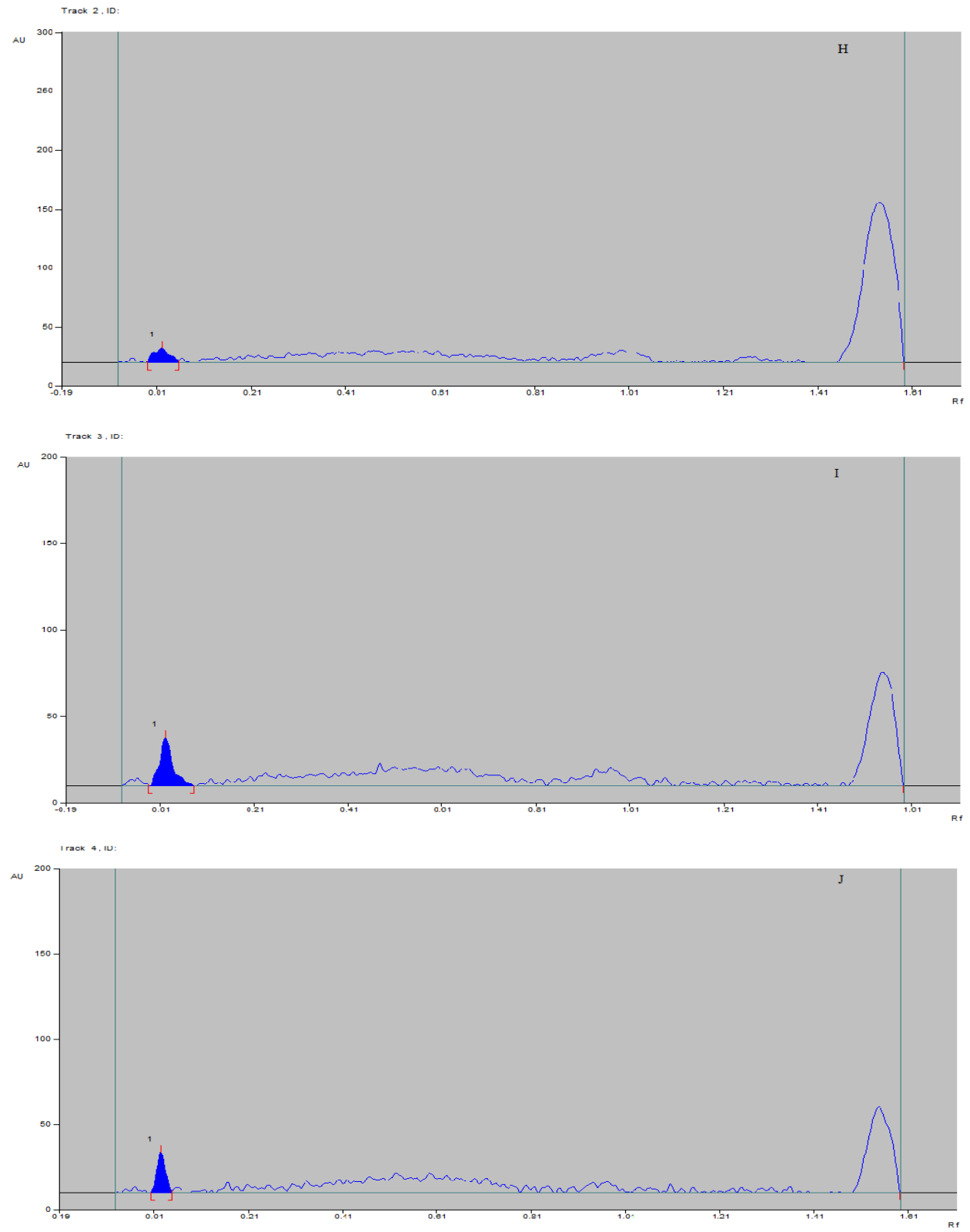
Track 3,10 :

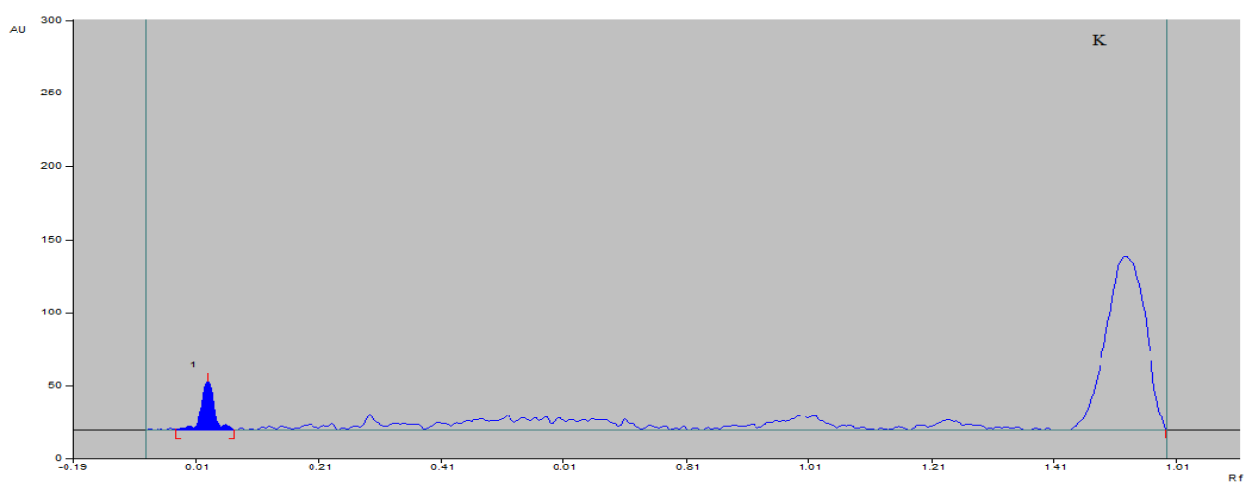

Fig. 1: HP-TLC curves for quantification of TMA conversion from standard choline (0.25 mg) in vitro at $254 \mathrm{~nm}$ and Rf 0.71-0.82(a) In nutrient broth. (b) In nutrient broth inoculated with Providencia rettgeri. (c) In nutrient broth inoculated with Providencia rettgeri containing choline. (d) In nutrient broth inoculated with Providencia rettgeri, choline and curcumin $(1 \mu \mathrm{g} / \mathrm{ml})$. (e) In nutrient broth inoculated with Providencia rettgeri, choline and curcumin $(5 \mu \mathrm{g} / \mathrm{ml})$. (f) In nutrient broth inoculated with Providencia rettgeri, choline and curcumin $(10 \mu \mathrm{g} / \mathrm{ml})$. (g) In nutrient broth inoculated with Providencia rettgeri, choline and curcumin $(20 \mu \mathrm{g} / \mathrm{ml})$. (h) In nutrient broth inoculated with Providencia rettgeri, choline and ciprofloxacin (1 $\mathrm{g} / \mathrm{ml})$. (i) In nutrient broth inoculated with Providencia rettgeri, choline and ciprofloxacin $(5 \mu \mathrm{g} / \mathrm{ml})$. (j) In nutrient broth inoculated with Providencia rettgeri, choline and ciprofloxacin $(10 \mu \mathrm{g} / \mathrm{ml}) .(\mathrm{k})$ In nutrient broth inoculated with Providencia rettgeri, choline and ciprofloxacin $(20 \mu \mathrm{g} / \mathrm{ml})$ 
TMA formed from choline in the presence and absence of curcumin and ciprofloxacin by Providencia rettgeri

HP-TLC analysis was performed to evaluate the amount of TMA synthesised from standard choline by Providencia rettgeri in the absence and presence of curcumin (table 2).

Samples containing curcumin were found to contain no detectable quantity of TMA, therefore it was concluded that curcumin inhibits the conversion of choline to TMA by Providencia rettgeri.

\section{In vivo studies}

Biochemical estimation was carried out and the results were as follows.
The mean serum triglyceride (TG) levels were calculated to be $52.14 \pm 1.138 \mathrm{mg} / \mathrm{dl}$ in $\mathrm{NC}, 78.6856 \pm 1.185 \mathrm{mg} / \mathrm{dl}$ in $\mathrm{PC}$ $60.3884 \pm 0.8075 \mathrm{mg} / \mathrm{dl}$ in CUR and $75.5816 \pm 2.116 \mathrm{mg} / \mathrm{dl}$ in CFX. The mean serum total cholesterol (TC) levels were calculated to be $118.673 \pm 1.148 \mathrm{mg} / \mathrm{dl}$ in $\mathrm{NC}, 159.0974 \pm 2.421 \mathrm{mg} / \mathrm{dl}$ in $\mathrm{PC}$ $145.938 \pm 1.593 \mathrm{mg} / \mathrm{dl}$ in CUR and $172.12 \pm 2.523 \mathrm{mg} / \mathrm{dl}$ in CFX. The mean serum HDL cholesterol levels were calculated to be $92.136 \pm$ $1.446 \mathrm{mg} / \mathrm{dl}$ in $\mathrm{NC}, 57.8312 \pm 1.176 \mathrm{mg} / \mathrm{dl}$ in $\mathrm{PC}, 101.2104 \pm 0.927$ $\mathrm{mg} / \mathrm{dl}$ in CUR and $67.7348 \pm 1.655 \mathrm{mg} / \mathrm{dl}$ in CFX. The mean serum LDL cholesterol levels were calculated to be $16.0952 \pm 1.194 \mathrm{mg} / \mathrm{dl}$ in NC, $86.4402 \pm 2.087 \mathrm{mg} / \mathrm{dl}$ in $\mathrm{PC}, 32.9226 \pm 1.533 \mathrm{mg} / \mathrm{dl}$ in CUR and $103.1468 \pm 12.43 \mathrm{mg} / \mathrm{dl}$ in CFX. The mean serum VLDL cholesterol levels were calculated to be $10.4276 \pm 0.2277 \mathrm{mg} / \mathrm{dl}$ in $\mathrm{NC}$ $15.7368 \pm 0.2369 \mathrm{mg} / \mathrm{dl}$ in PC, $12.2774 \pm 0.2416 \mathrm{mg} / \mathrm{dl}$ in CUR and $15.116 \pm 0.4232 \mathrm{mg} / \mathrm{dl}$ in CFX (table 3 ).

Table 3: Effect of curcumin of serum various cholesterol and triglyceride levels in C57BL/6J mice

\begin{tabular}{|c|c|c|c|c|c|}
\hline Group Name & $\mathrm{TC}^{*}(\mathrm{mg} / \mathrm{dl})$ & TG* $^{*}(\mathrm{mg} / \mathrm{dl})$ & $\mathrm{LDL}^{*}(\mathrm{mg} / \mathrm{dl})$ & VLDL* (mg/dl) & HDL $^{*}(\mathrm{mg} / \mathrm{dl})$ \\
\hline $\mathrm{NC}$ & $118.673 \pm 1.148$ & $52.14 \pm 1.138$ & $16.0952 \pm 1.194$ & $10.4276 \pm 0.2277$ & $92.136 \pm 1.446$ \\
\hline PC & $159.0974 \pm 2.421$ & $78.6856 \pm 1.185$ & $86.4402 \pm 2.087$ & $15.7368 \pm 0.2369$ & $57.8312 \pm 1.176$ \\
\hline CUR & $145.938 \pm 1.593$ & $60.3884 \pm 0.8075$ & $32.9226 \pm 1.533$ & $12.2774 \pm 0.2416$ & $101.2104 \pm 0.927$ \\
\hline CFX & $172.12 \pm 2.523$ & $75.5816 \pm 2.116$ & $103.1468 \pm 12.43$ & $15.116 \pm 0.4232$ & $67.7348 \pm 1.655$ \\
\hline
\end{tabular}

Values are expressed as mean \pm SEM, $n=5$, TC Total cholesterol, TG-triglycerides, HDL-high density lipoprotein, LDL-low density lipoprotein, VLDLvery low density lipoprotein

The mean Atherogenic Risk Factor (ARF) was calculated to be $0.2048 \pm 0.1826$ in NC, $1.5 \pm 0.0378$ in PC, $0.3278 \pm 0.0165$ in CUR and $1.26 \pm 0.0503$ in CFX. The mean Coronary Risk Index (CRI) was calculated to be $1.53 \pm 0.01703$ in NC, $2.728 \pm 0.0548$ in PC, $1.4542 \pm$ 0.01479 in CUR and $2.448 \pm 0.03397$ in CFX.

\section{Ex vivo studies}

Liver homogenates prepared from different groups were incubated with TMA and then analyzed by HP-TLC for the detection of amount of unreacted TMA (table 4). The amount of TMA detected was corelated with the amount of TMAO formed by the enzyme $\mathrm{FMO}_{3}$ Therefore, greater the concentration of TMA (that is, lesser TMAO formed) would imply the decreased activity of $\mathrm{FMO}_{3}$ enzyme.
Table 4: Mean concentration of TMA left unreacted in liver homogenate samples of various groups

\begin{tabular}{lll}
\hline Group No. & Group name & $\begin{array}{l}\text { Concentration of TMA left } \\
\text { unreacted }^{*}(\mathbf{n g} / \boldsymbol{\mu l})\end{array}$ \\
\hline I & NC & $709.786 \pm 18.425$ \\
II & PC & $727.937 \pm 31.916$ \\
III & CUR & $865.452 \pm 44.839$ \\
IV & CFX & $641.977 \pm 21.732$ \\
\hline
\end{tabular}

${ }^{*}$ Values are expressed as mean \pm SEM, $n=5$, TMA-trimethylamine, NCnormal control, PC-pathogenic control, CUR-curcumin treated mice, CFX-ciprofloxacin-treated mice.

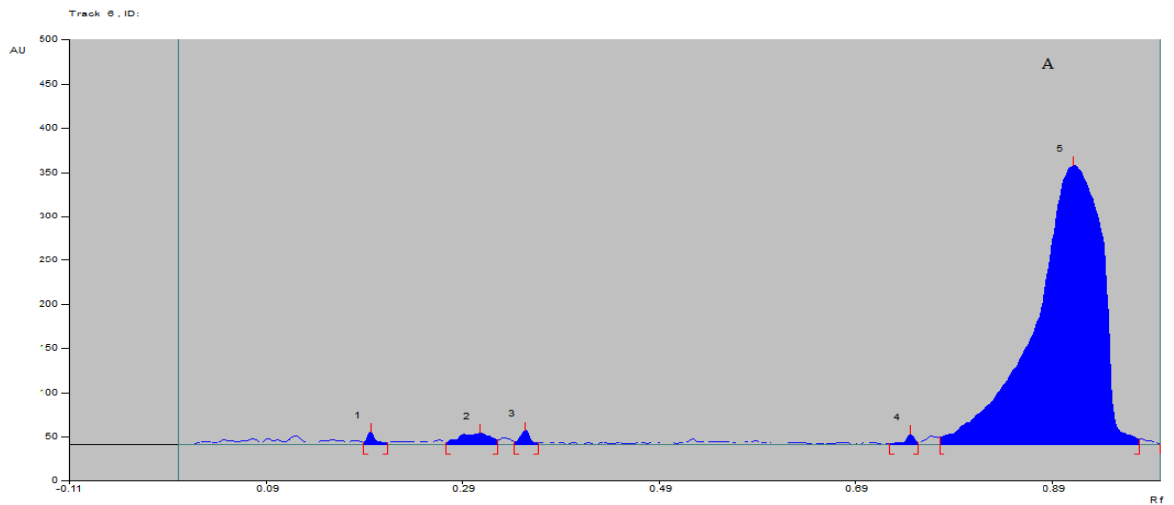

Track 7.10 .

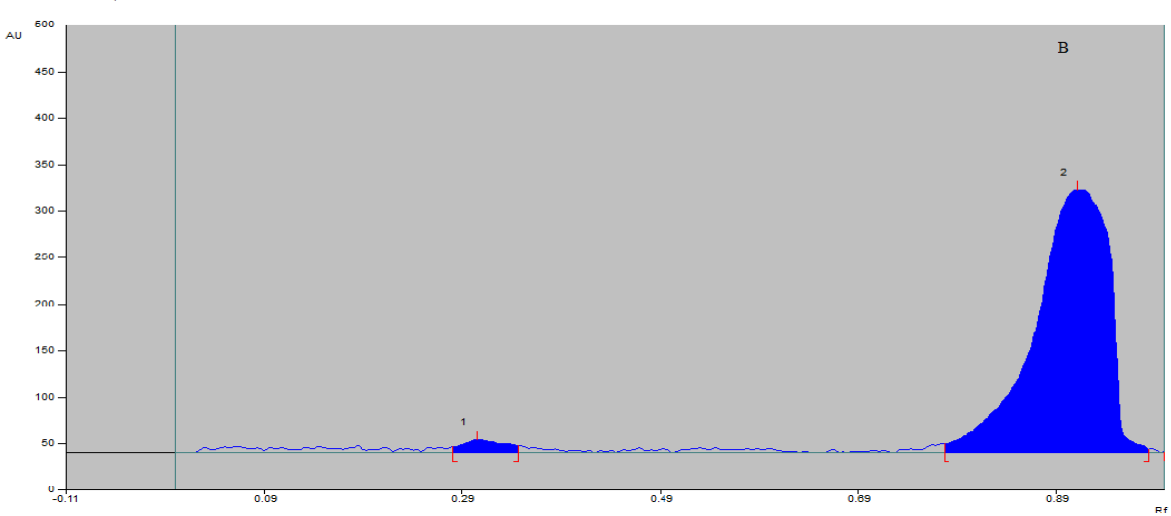




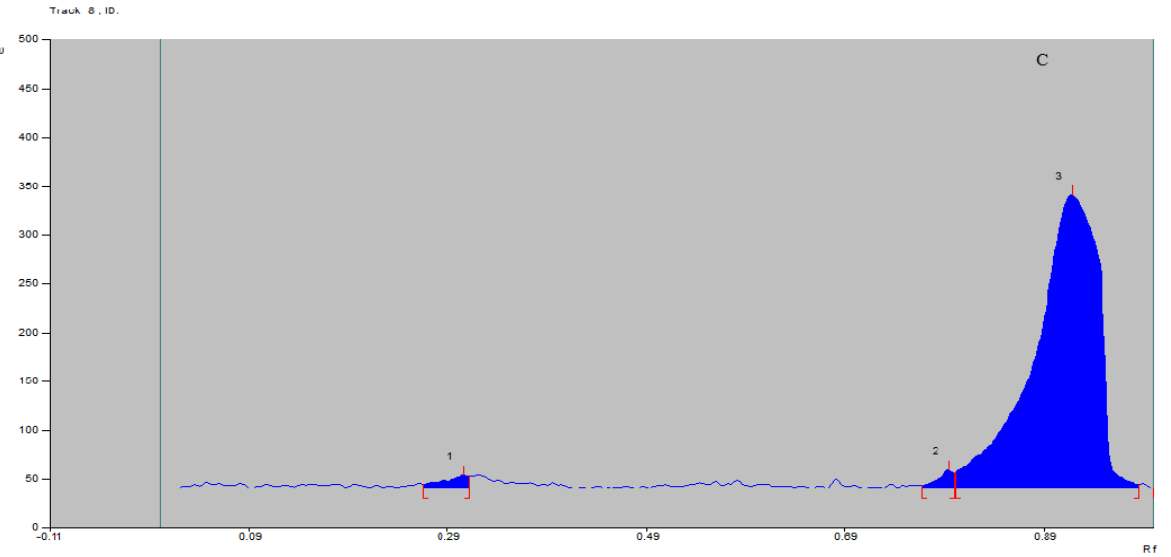
Track 9, ID:
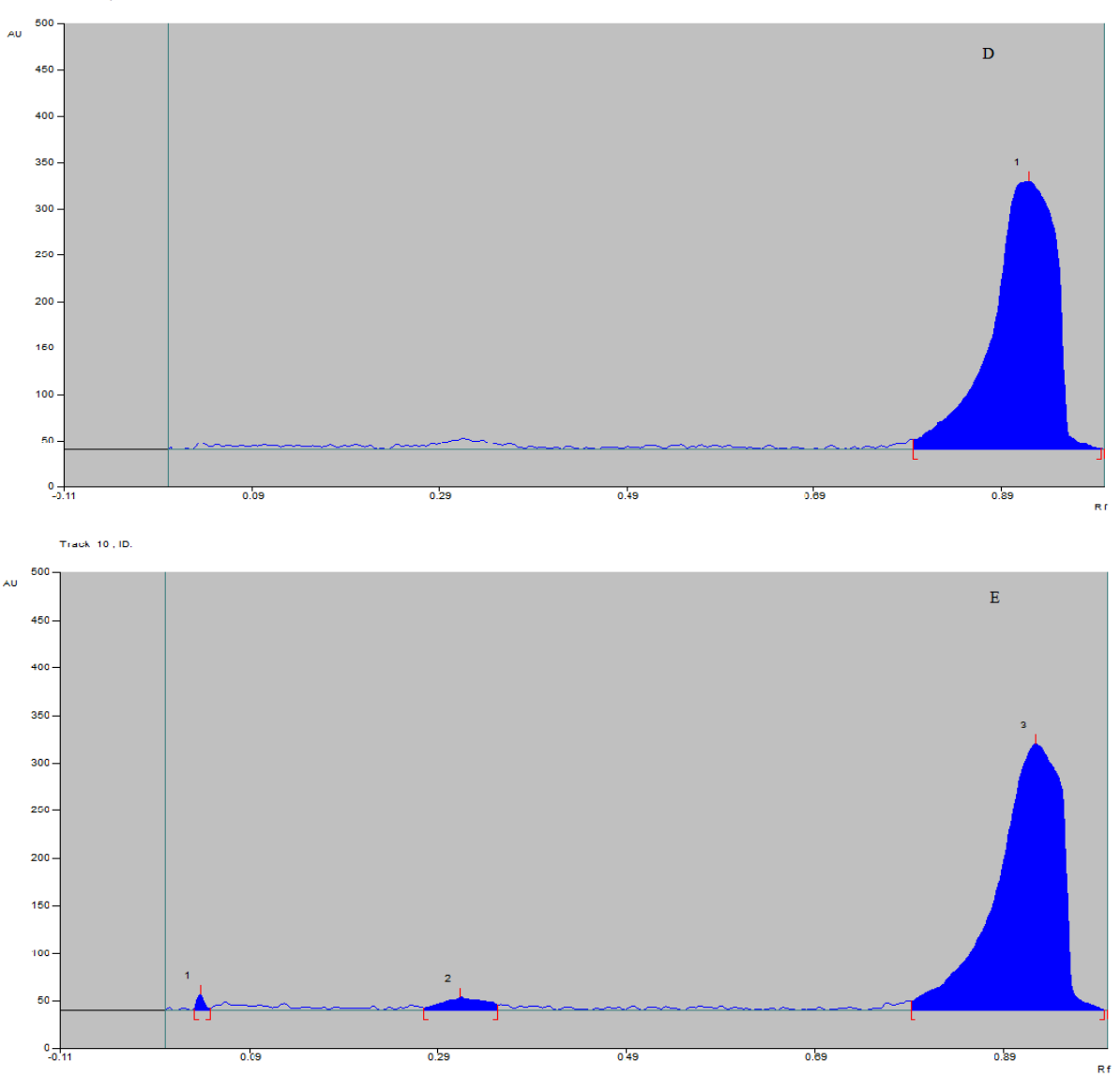
Traok 10.10

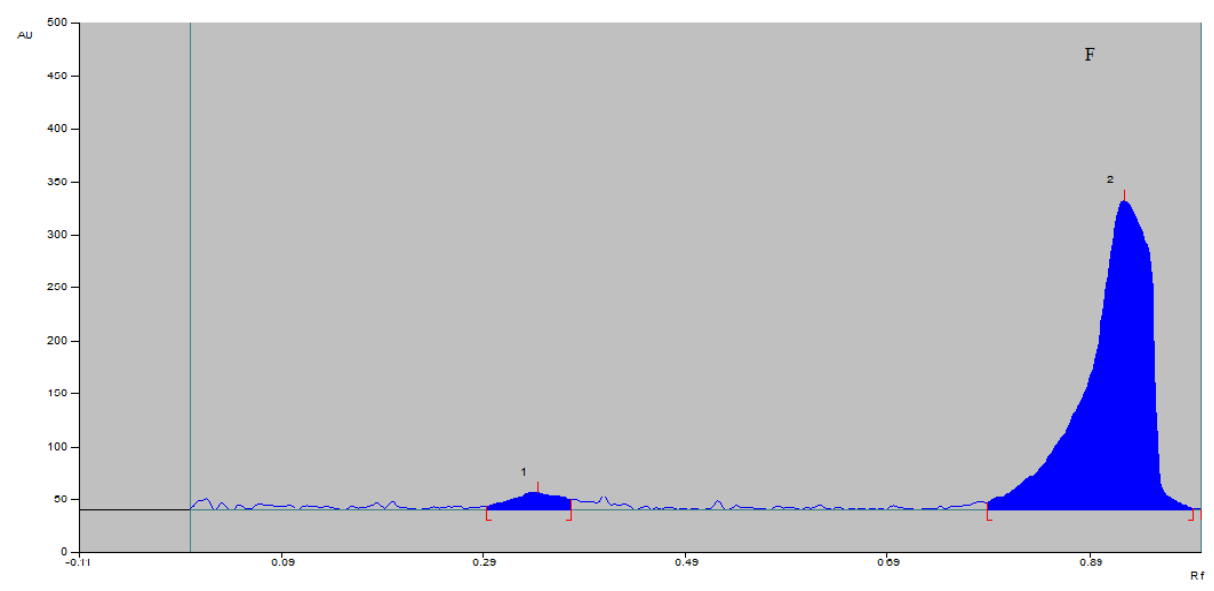



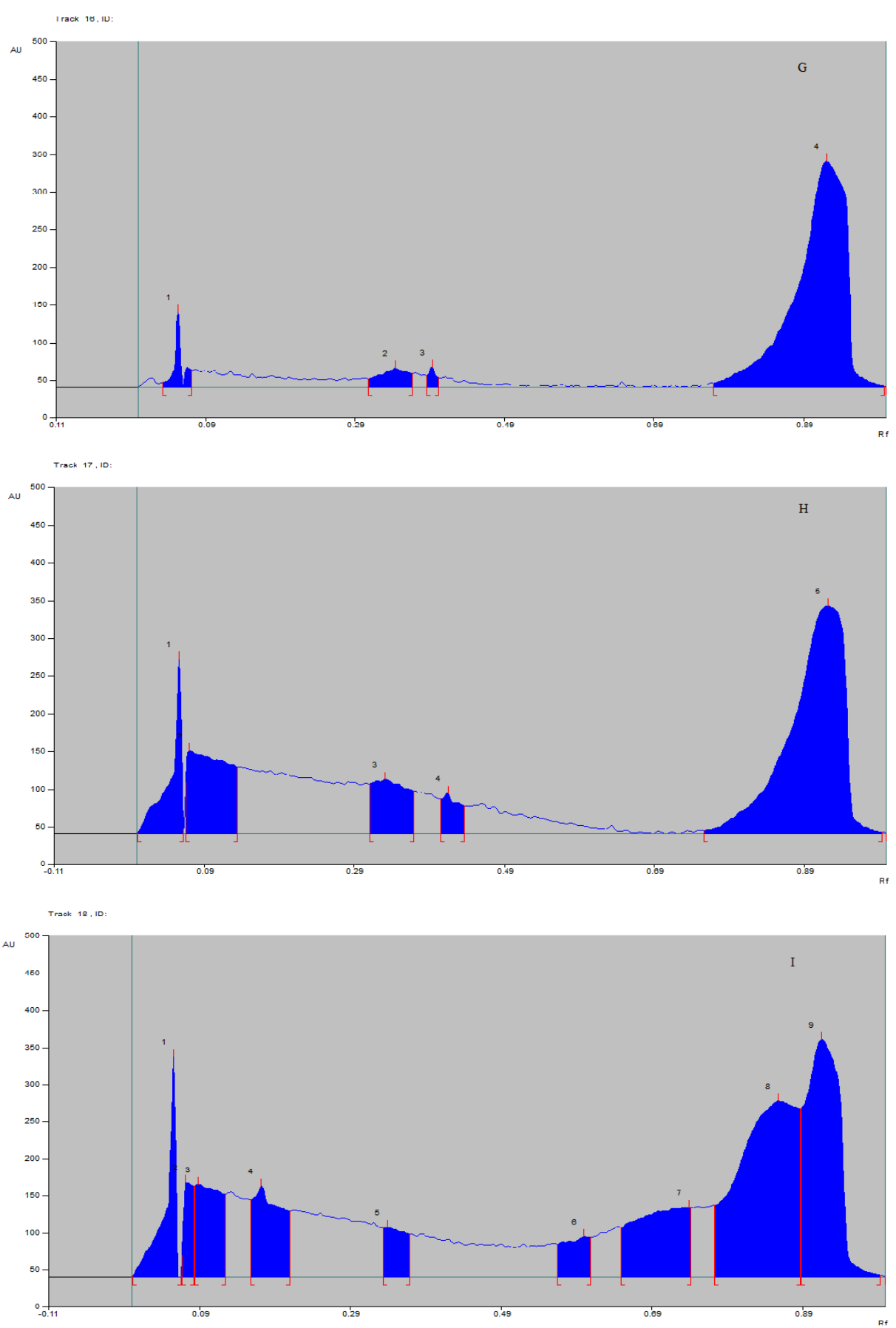

Irack 6.10

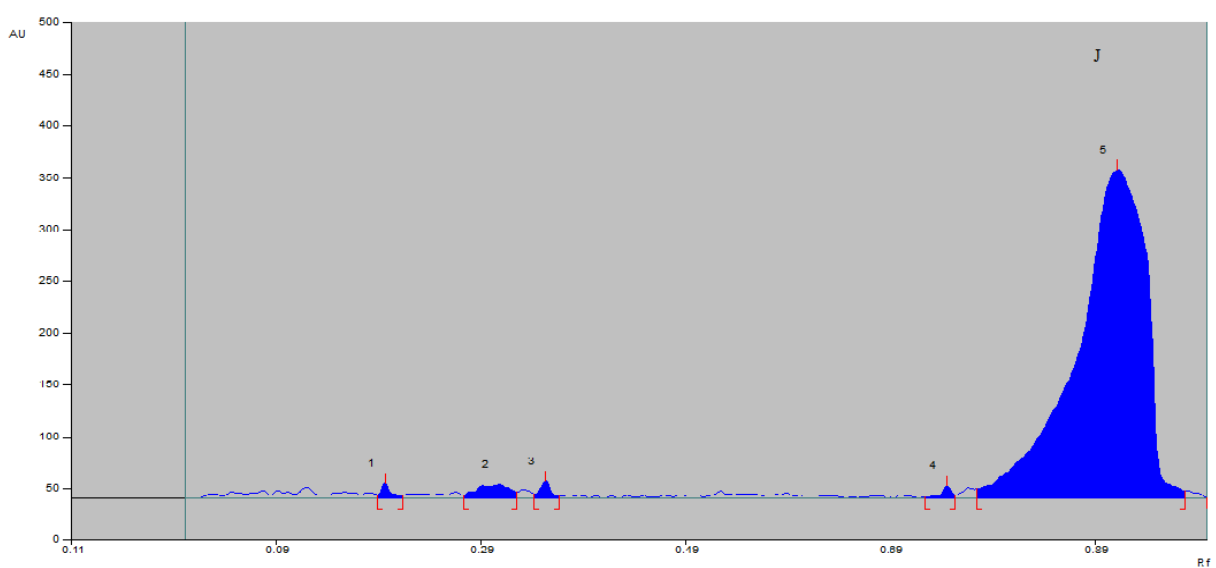




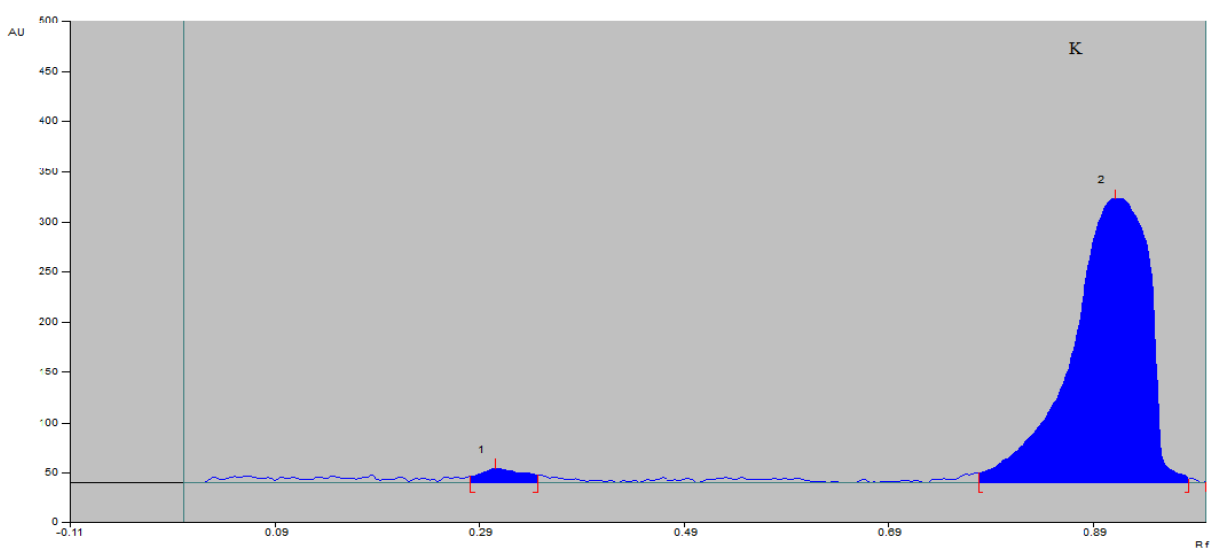

Tati 8.10

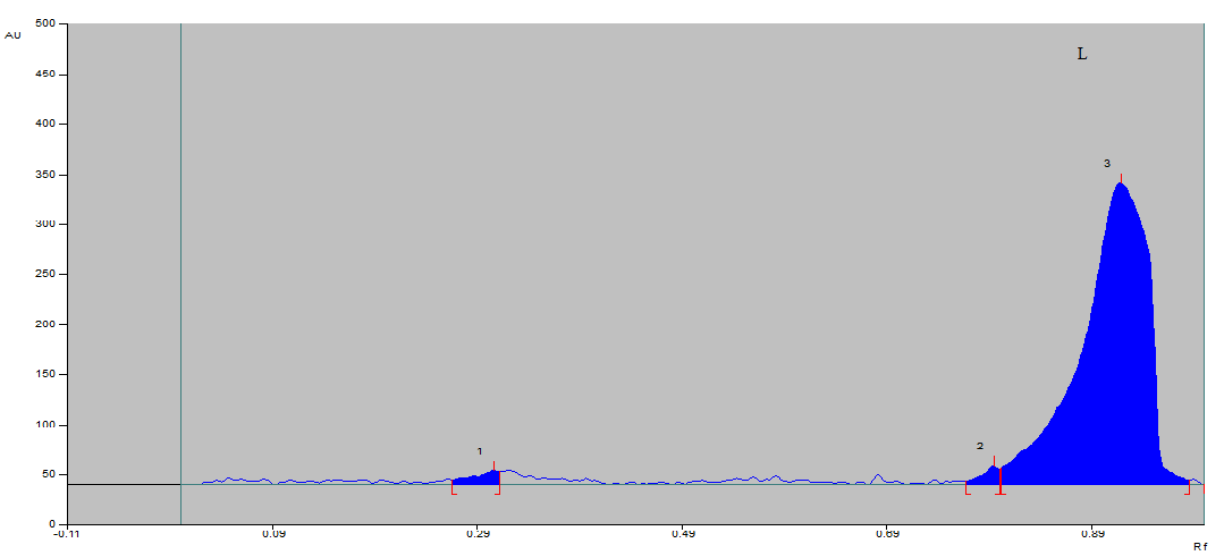

Track 9, 10:

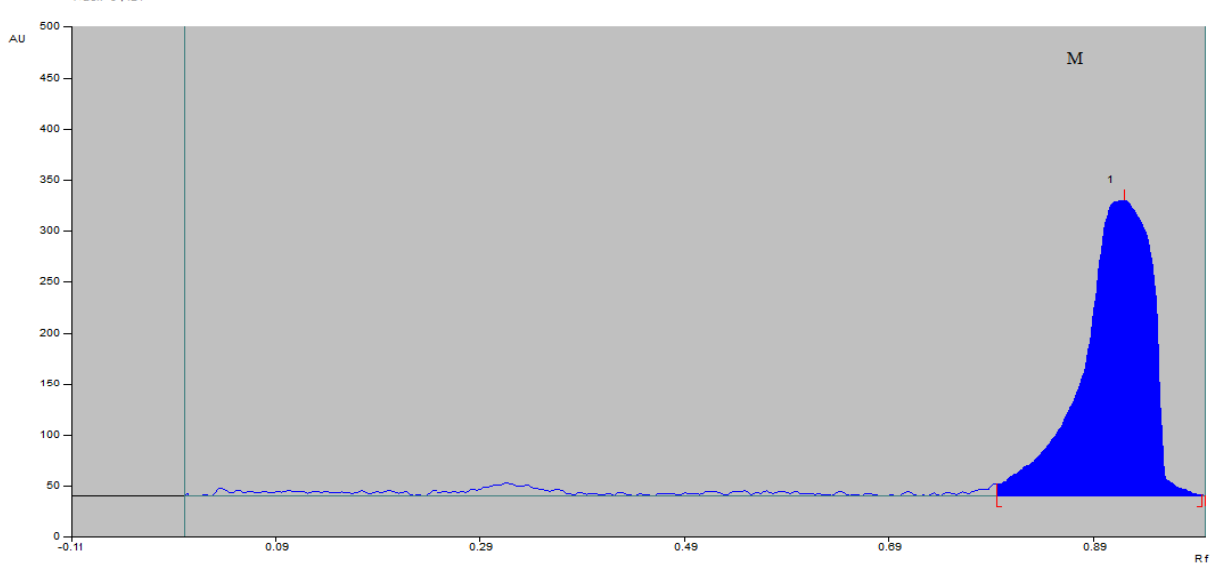

Track 10 ,

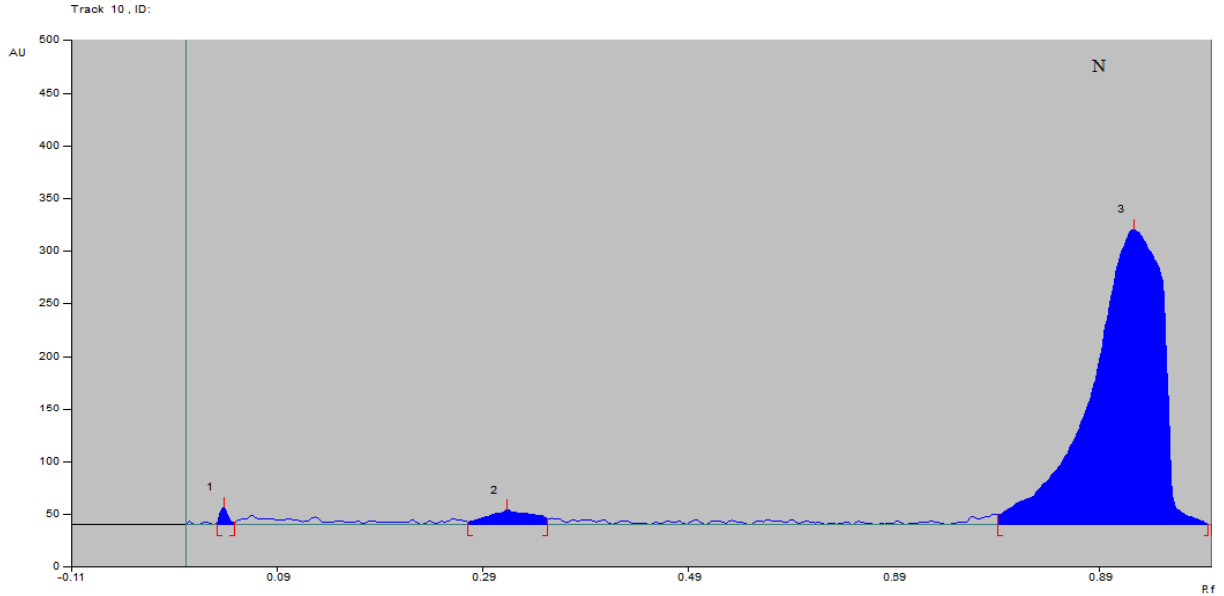



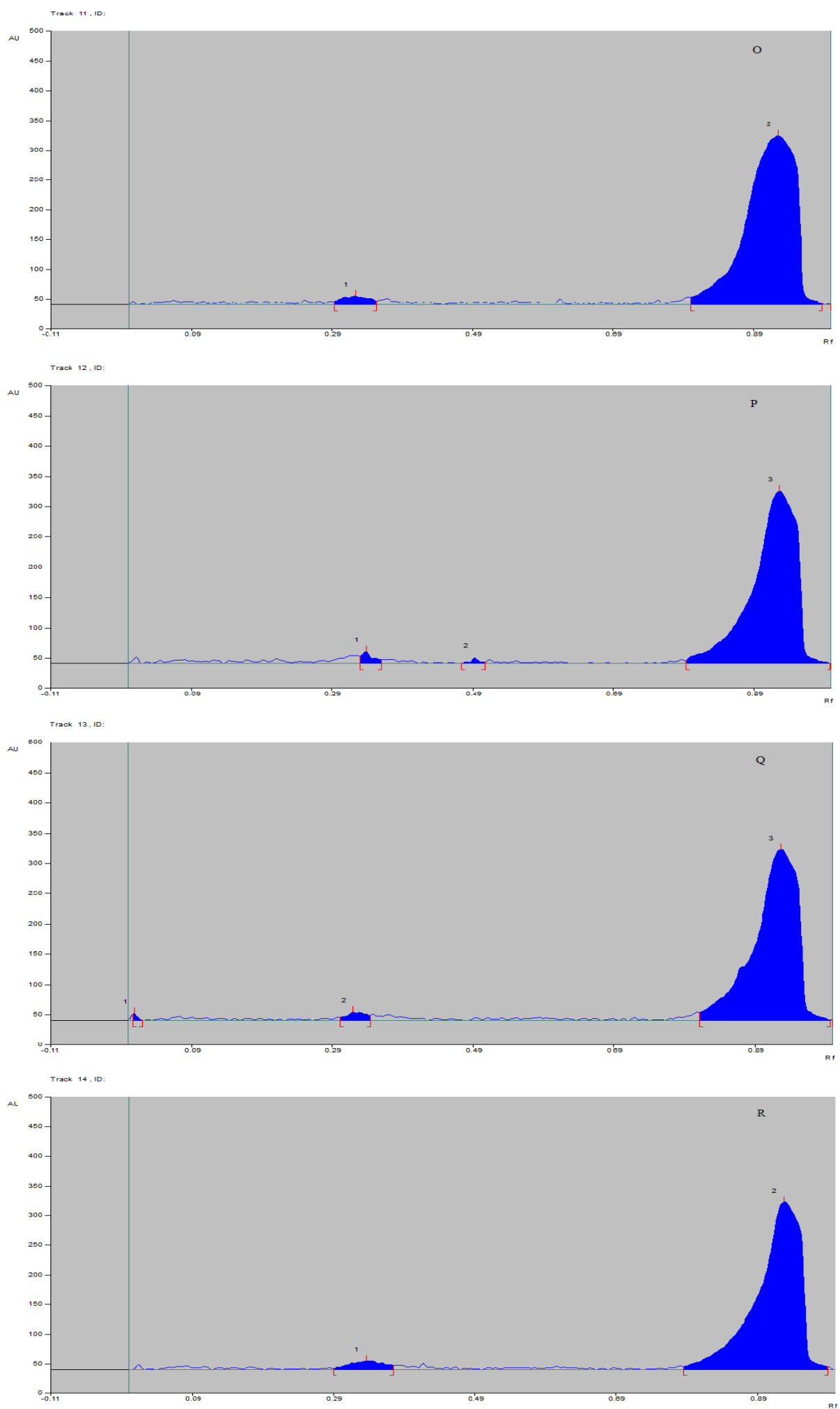

Fig. 2: HP-TLC curves for the quantification of TMA left unreacted to produce TMAO in (a) Normal control homogenate sample containing $0.1 \%$ TMA solution. (b) Normal control homogenate sample containing $0.2 \%$ TMA solution. (c) Normal control homogenate sample containing $0.3 \%$ TMA solution. (d) Normal control homogenate sample containing $0.4 \%$ TMA solution. (e) Normal control homogenate sample containing $0.5 \%$ TMA solution. (f) Pathogenic control homogenate sample containing 0.1\% TMA solution. (g) Pathogenic control homogenate sample containing $0.2 \%$ TMA solution. (h) Pathogenic control homogenate sample containing 0.3\% TMA solution. (i) Pathogenic control homogenate sample containing 0.4\% TMA solution. (j) Curcumin-treated group homogenate sample containing 0.1\% TMA solution. (k) Curcumin-treated group homogenate sample containing $0.2 \%$ TMA solution. (l) Curcumin-treated group homogenate sample containing $0.3 \%$ TMA solution. (m) Curcumin-treated group homogenate sample containing 0.4\% TMA solution. (n) Curcumin-treated group homogenate sample containing 0.5\% TMA solution. (o) Ciprofloxacin-treated group homogenate sample containing $0.1 \%$ TMA solution. (p) Ciprofloxacin-treated group homogenate sample containing $0.2 \%$ TMA solution (q) Ciprofloxacin-treated group homogenate sample containing $0.3 \%$ TMA solution. (r) Ciprofloxacintreated group homogenate sample containing $0.4 \%$ TMA solution at $254 \mathrm{~nm}$ and $\mathrm{Rf}$ 0.73-0.79 
The samples of different groups were compared to those of the normal control group samples (table 5), and the percentage change in $\mathrm{FMO}_{3}$ activity was calculated taking the $\mathrm{FMO}_{3}$ activity in normal control (group I) samples to be $100 \%$. Therefore, it was concluded that curcumin shows $\mathrm{FMO}_{3}$ inhibiting activity.

Table 5: Comparison of mean change in the $\mathrm{FMO}_{3}$ activity of various groups

\begin{tabular}{lll}
\hline Group No. & Group name & Mean change in $\mathrm{FMO}_{3}$ activity* \\
\hline I & NC & 100 \\
II & PC & $1.694 \pm 6.601$ \\
III & CUR & $-21.5796 \pm 3.407$ \\
IV & CFX & $8.372 \pm 0.4106$ \\
\hline
\end{tabular}

*Values are expressed as mean $\pm \mathrm{SEM}, n=5, \mathrm{FMO}_{3}$-flavin monooxygenase III

\section{DISCUSSION}

Atherosclerosis is a complex process by which arteries progressively narrowed, impairing the supply of oxygen and nutrients to the tissues. Atherosclerotic plaques can also rupture, triggering formation of a clot and an abrupt loss of blood supply to tissues that results in infarction [7]. The pathogenesis of cardiovascular diseases includes genetic and environmental factors. According to Wang et al. [1], there is a role of gut microbiota on the phosphatidylcholine metabolism which can be the cause of major vascular disease. Choline, a trimethylamine and part of the head group of phosphatidylcholine, is metabolized by gut microbiota to produce an intermediate compound known as trimethylamine (TMA). TMA is rapidly further oxidized by hepatic Flavin monooxygenases to form trimethylamine-N-oxide (TMAO). TMAO was shown to be both proatherogenic and associated with cardiovascular risks. TMAO inhibits reverse cholesterol transport and also reduces bile acid synthesis, both of which are associated with increased atherosclerosis [9].

Though many studies have shown that antibiotics have markedly reduced the level of TMAO, clinically it has not been in practice. Even if $1 \%$ if these microbes have resistance to the antibiotics, in the beginning it looks as though $99 \%$ of TMAO has been inhibited. But after $20 \mathrm{w}$, the microbial population comes to normal.

India, having a rich tradition of folk medicine for centuries, has provided simple but effective remedies to various ailments using plant-derived products. Among these phytoceuticals, curcumin, the main constituent of spice turmeric has attracted attention due to its ability to exert beneficial effects in multiple pathological conditions.

Very few studies have been performed to assess the potential of Curcumin as an anti-atherosclerotic agent, one of them being "Effect of Curcumin on Atherosclerosis in apoE/IDLR-Double knockout mice" by Olszanecki et al. in 2005 [21]. This study focused on the effect of Curcumin on the reduction of lipid lesion area in aorta in apoE/IDLR-Double knockout mice which were fed with Western Diet, and Olszanecki et al. concluded that curcumin, given orally at a relatively low dose, was able to decrease formation of atherosclerotic changes in apoE/IDLR-DKO mice fed with Western diet. However, there has been no study yet to determine the efficacy of curcumin in preventing as well as treating the alterations induced by the gut flora which lead to conversion of TMA to TMAO, both of which are well established pro-atherosclerotic markers.

The present study was based on evaluation of the potential of curcumin on the inhibition of conversion of choline to TMA, and further its conversion to TMAO in liver. The conversion of TMA to TMAO is catalyzed by the enzyme $\mathrm{FMO}_{3}$ in liver. Therefore, the $\mathrm{FMO}_{3}$ inhibiting potential of curcumin was assessed in this study. Also, the conversion of choline to TMA by gut microbiota was assessed in the presence and absence of curcumin in order to determine whether curcumin can prevent the production of pro-atherogenic TMAO, and the precursor for its synthesis, i.e., TMA.

Anti-microbial efficacy was evaluated by cup plate method. The agar plate of the standard drug, ciprofloxacin $(50 \mu \mathrm{g} / \mathrm{ml})$ showed significant zone of inhibition whereas, the agar plate of the test drug, curcumin also showed significant zone of inhibition at various concentrations $(10,25,50,100 \mu \mathrm{g} / \mathrm{ml})$, table $1 . \mathrm{k}$ The minimum inhibitory concentration (MIC) of curcumin was determined to be 10 $\mu \mathrm{g} / \mathrm{ml}$, thus concluding curcumin's anti-bacterial activity against the gut microbe Providencia rettgeri.

HP-TLC analysis was performed to evaluate the amount of TMA synthesized from standard choline by Providencia rettgeri in the absence and presence of curcumin. Various samples containing Providencia rettgeri along with curcumin at varying concentrations $(0,1,5,10,20 \mu \mathrm{g} / \mathrm{ml})$ were incubated to determine the conversion of choline to TMA. No detectable concentration of TMA was found in the samples containing curcumin (table 2). Therefore, it can be concluded that curcumin prevents the conversion of choline to TMA. In vivo studies were performed by feeding $2 \%$ choline diet to female C57BL/6J mice for $21 \mathrm{~d}$. The choline given in diet was metabolized to produce TMAO by the gut microbiota, which played a significant role in increasing total cholesterol levels. Triglyceride levels, CRI and ARF values.

There was a significant increase $(p<0.001)$ in the mean total cholesterol levels in the PC (group II) mice as compared to NC (group I) mice. Treatment with curcumin (group III) slightly decreased $(p<0.01)$ the mean TC levels as compared to PC (group II) mice. Also, there was no significant decrease $(p<0.01)$ in the mean TC levels in mice treated with ciprofloxacin (CFX, group IV) as compared to PC (group II). Also, the effect of both the test drug (curcumin) and the standard drug (ciprofloxacin) was found to be comparable in the reduction of serum TC levels.

There was a significant increase $(\mathrm{p}<0.001)$ in the mean triglyceride (TG) levels in the PC (group II) mice as compared to NC (group I) mice. Treatment with curcumin significantly decreased the mean TG levels as compared to PC mice $(\mathrm{p}<0.001)$. Also, there was no significant decrease $(\mathrm{p}<0.01)$ in the mean TG levels in mice treated with ciprofloxacin (CFX) as compared to choline-fed mice (PC). Also, the effect of curcumin on reduction of serum TG levels was found to be highly significant as compared to ciprofloxacin.

There was a significant decrease $(p<0.001)$ in the mean HDL cholesterol levels in the PC (group II) mice as compared to NC (group I) mice. HDL levels in curcumin-treated mice (group III) increased extremely significantly $(\mathrm{p}<0.001)$ as compared to HDL levels PC mice. Also, there was a significant increase $(p<0.001)$ in the mean HDL levels in mice treated with ciprofloxacin (CFX, group IV) as compared to choline-fed mice (PC, group II). Furthermore, the effect of curcumin on the increase of serum HDL levels was found to be comparable to that produced by ciprofloxacin.

There was a significant increase $(\mathrm{p}<0.001)$ in the mean LDL and VLDL cholesterol levels in the PC (group II) mice as compared to NC (group I) mice. LDL and VLDL levels in curcumin-treated mice (group III) decreased extremely significantly $(p<0.001)$ as compared to LDL and VLDL levels PC mice. Also, there was no significant decrease $(p>0.05)$ in the mean LDL and VLDL levels in mice treated with ciprofloxacin (CFX, group IV) as compared to choline-fed mice (PC, group II). Furthermore, the effect of curcumin on the decrease of serum LDL and VLDL levels was found to be highly significant to that produced by ciprofloxacin.

Therefore, it was concluded that treatment with curcumin $(30$ $\mathrm{mg} /$ mice/day) produced significant reduction in mean serum total cholesterol, triglyceride, LDL and VLDL-cholesterol, and also significantly increased serum HDL levels.

Liver homogenates prepared from different groups namely $\mathrm{NC}$ (group I), PC (group II), CUR (group III) and CFX (group IV) were incubated with TMA and then analyzed by HP-TLC for the detection of amount of unreacted TMA. The amount of TMA detected was corelated with the amount of TMAO formed by the enzyme $\mathrm{FMO}_{3}$ Therefore, greater the concentration of TMA (that is, lesser TMAO formed) would imply the decreased activity of $\mathrm{FMO}_{3}$ enzyme.

The average concentration of TMA left unreacted was calculated, and found to be $(709.786 \pm 18.425) \mathrm{ng} / \mu \mathrm{l}$ in the normal control (group I) samples and $(865.332 \pm 1088.3) \mathrm{ng} / \mu \mathrm{l}$ in curcumin-treated 
(group III) samples. Also, the samples of different groups were compared to those of the normal control group samples, and the percentage change in $\mathrm{FMO}_{3}$ activity was calculated taking the $\mathrm{FMO}_{3}$ activity in normal control (group I) samples to be $100 \%$. Therefore, it was concluded that curcumin shows $\mathrm{FMO}_{3}$ inhibiting activity.

\section{CONCLUSION}

In conclusion, the present study demonstrates the efficacy of curcumin in preventing the conversion of choline to TMA by Providencia rettgeri as well the conversion of TMA to TMAO by inhibiting liver $\mathrm{FMO}_{3}$ enzyme in $\mathrm{C} 57 \mathrm{BL} / 6 \mathrm{~J}$ mice. The minimum inhibitory concentration (MIC) of curcumin was determined to be 10 $\mu \mathrm{g} / \mathrm{ml}$, thus concluding curcumin's anti bacterial activity against the gut microbe Providencia rettgeri. HP-TLC analysis was performed to evaluate the amount of TMA synthesized from standard choline by Providencia rettgeri in the absence and presence of curcumin. Various samples containing Providencia rettgeri along with curcumin at varying concentrations $(0,1,5,10,20 \mu \mathrm{g} / \mathrm{ml})$ were incubated to determine the conversion of choline to TMA. The concentration of TMA was found to be maximum in the sample containing no curcumin. Whereas, in the samples containing curcumin, no TMA was detected. Therefore, it can be concluded that curcumin prevents the conversion of choline to TMA. In C57BL/6J mice fed with choline diet and treated with curcumin showed significant reduction in serum TG, TC, LDL and VLDL levels and a significant increase HDL levels. Liver homogenates prepared from different groups namely NC (group I), PC (group II), CUR (group III) and CFX (group IV) were incubated with TMA and then analyzed by HP-TLC for the detection of amount of unreacted TMA. The amount of TMA detected was co-related with the amount of TMAO formed by the enzyme $\mathrm{FMO}_{3}$. Therefore, greater the concentration of TMA (that is, lesser TMAO formed) would imply the decreased activity of $\mathrm{FMO}_{3}$ enzyme. Thus, it can be concluded that curcumin has the potential to prevent the formation of proatherosclerotic metabolites TMA and TMAO, as well as has a hypolipidaemic action in choline fed C57BL/6J mice.

\section{CONFLICT OF INTERESTS}

\section{Declared none}

\section{REFERENCES}

1. Wang Z, Klipfell E, Bennett B, Koeth R, Levison B, DuGar B, et al. Gut flora metabolism of phosphatidylcholine promotes cardiovascular disease. J Nat 2011;472:57-65.

2. Al-Waiz M, Mikov M, Mitchell SC, Smith RL. The exogenous origin of trimethylamine in the mouse. J Metabol 2007;41:135-6.

3. DaCosta KA, Vrbanac JJ, Zeisel SH. The measurement of dimethylamine, trimethylamine trimethylamine-N-oxide using capillary gas chromatography-mass spectrometry. J Anal Biochem 1990;187:234-9.

4. Lang DH, Yeung CK, Peter RM, Ibarra C, Gasser R, Itagaki G, et al. Isoform specificity of trimethylamine $N$-oxygenation by human flavin-containing monooxygenase (FMO) and P450 enzymes: selective catalysis by fmo3. Biochem Pharmacol 1998;56:1005-12.

5. Mitchell SC, Smith RL. Trimethylaminuria: the fish malodor syndrome. Drug Metab Dispos 2001;29:517-21.

6. Schadt EE, Lamb J, Yang X, Zhu J, Edwards S, Guhathakurta D, et al. An integrative genomics approach to infer causal associations between gene expression and disease. Nature Genet 2005;37:710-7.

7. Koeth RA, Wang Z, Levison BS, Buffa JA, Org E, Sheehy B, et al. Intestinal microbiota metabolism of L-carnitine, a nutrient red meat, promotes atherosclerosis. J Nat Med 2013;19:576-85.

8. Jawein J. Mouse experimental models of atherosclerosis in pharmacology. J Clin Exp Cardiol 2011;10:211-55.

9. Tang W, Wang Z, Levison B, Koeth R, Britt E, Fu X, et al. Intestinal microbial metabolism of phosphatidylcholine and cardiovascular disease. New Eng J Med 2013;369:1575-84.

10. Rudrappa T, Bais HP. Curcumin, a known phenolic from Curcuma longa, attenuates the virulence of Pseudomonas aeruginosa PA01 in whole plant and animal pathogenicity models. J Agric Food Chem 1962;56:200.
11. Lee CJ, Lee JH, Seok GH, Hur GM, Park YC, Seol IC, et al. Effects of baicalein, berberine, curcumin and hespiridin on mucin release from airway goblet cells. J Plant Med 2003;69:523-6.

12. Shukla Y, Arora A. Suppression of altered hepatic foci development by curcumin in Wistar rats. J Nutr Cancer 2003;45:53-9.

13. Jentzsch K, Gonda T, Holler H. Paper chromatographic and pharmacological investigations on curcuma pigments. Pharm Acta Helvitiae 1959;34:181-8.

14. Patel K, Srinivasan K. Influence of dietary spices and their active principles on pancreatic digestive enzymes in albino rats. Nahrung 2000;44:42-6.

15. Nirmala C, Puvanakrishnan R. Protective role of curcumin against isoproterenol-induced myocardial infarction in rats. J Mol Cell Biol 1996;159:85-93.

16. Brouet I, Ohshima. Curcumin, an antitumor promoter and antiinflammatory agent, inhibits induction of nitric oxide synthase in activated macrophages. Biochem Biophy Res Comm 1995;206:533-40.

17. Srimal RC, Dhawan BN. In development of unani drugs from herbal sources and the role of elements in their mechanism of Action. Hamdard National Foundation Monograph: New Delhi; 1985. p. 256.

18. Sharma OP. Antioxidant activity of curcumin and related compounds. J Biochem Pharmacol 1976;25:1811-2.

19. Chen HW, Huang HC. Effect of curcumin on cell cycle progression and apoptosis in vascular smooth cells. $\mathrm{Br} J$ Pharmacol 1998;124:1029-40.

20. Piedrahita JA, Zhang SH, Hagaman JR, Oliver PM, Maeda N. Generation of mice carrying a mutant apolipoprotein E gene inactivated by gene targeting in embryonic stem cells. Proc Natl Acad Sci USA Genetics 1992;89:4471-5.

21. Subhapriya S, Tomi L, Padmanaban VC. Atherosclerosis: critical role of oxidation and inflammation. Int J Pharm Pharm Sci 2013;5:6-7.

22. Olszanecki R, M Jawien J, Gajda M, Mateuzuk L, Gebska A, Korabiowska M, et al. Effect of curcumin on atherosclerosis in apoE/lDLR-double knockout mice. J Physiol Pharmacol 2005;56:627-35.

23. Nakashima Y, Plump AS, Raines EW, Breslow JL, Ross R. ApoEdeficient mice develop lesions of all phases of atherosclerosis throughout the arterial tree. Arterioscler Thromb 1994;14:133-40.

24. Kapakos G, Youreva V, Srivastava AK. Cardiovascular protection by curcumin. Indian J Biochem Biophys 2012;49:306-15.

25. Rose SB, Miller RE. Studies with agar cup plate method. J Bacteriol 1939;38:246-54.

26. Demacher PN, Hijamaus AG, Janssen HE, Laar A, Jansen AP. A study of the use of polyethylene glycol in estimating cholesterol. J Clin Chem 1980;26:1775-8.

27. Foster LB, Dunn RT. Stable reagents for the determination of serum triglycerides by colorimetric Hantzch condensation method. J Clin Chem 1973;19:338-40.

28. Burstein M, Scholnick HR, Morfix R. Rapid method for isolation of lipoproteins from human serum by precipitation with polyanions. J Lipid Res 1970;11:583-95.

29. Friedwald WT, Levy RI, Friedrick DS. Estimation of the concentration of Low-density Lipoprotein Cholesterol without use of preparative ultracentrifuge. J Clin Chem 1972;18:499-502.

30. Dobiasova M, Frohlich J. The plasma parameter log (TG/HDL-C) as an atherogenic index: correlation with lipoprotein particle size and esterification rate in apoB-lipoprotein-depleted plasma (FERHDL). J Clin Biochem 2001;34:583-8.

31. Kamath SA, Kummerow FA, Narayan KA. A simple procedure for the isolation of rat liver microsomes. Fed Eur Biochem Soc Lett 1971;17:90-2.

How to cite this article

- $\quad$ Himani Joshi, Uma Bhandari, Bibhu Prasad Panda. To assess the potential of curcumin against gut microbiota-induced alteration in choline metabolism in C57BL/6J mice. Int J Pharm Pharm Sci 2017;9(3):215-226. 